The Geneva Papers on Risk and Insurance, 8 (No 28, July 1983), 192-200

\title{
The Economic Significance of Private Insurance Business
}

\author{
by Wolfgang Schieren *
}

It seems to me that the idea the notorious " man in the street", and indeed the public at large, have formed of the function of insurance business and the way insurance functions is, to say the least, still rather vague. To explain why there should be such barriers to better understanding and where the ultimate reason lies would in itself provide the subject for a whole paper. Here I cannot but trace out the broad outline of the problem. Among other things, the whole matter at issue is clearly related to the fact that to most people the invisible economic good "insurance" appears to be an exceedingly intricate mesh of legal relationships, hardly intelligible to persons lacking legal training. The attempt to locate the actual position of insurance in the business world and to describe its functions is further complicated by the fact that the activities of this service industry are becoming ever more deeply intertwined with practically every other sector of our economy. One final factor which might play a role in this connection is that the legislators responsible for the set-up of insurance markets are clearly guided by other criteria than clarity and intelligibility.

If we want to throw a little light on this matter, we must begin by realising that there is both a quantitative and a qualitative side to the concept of " economic significance". In the first part of my paper an overview of the international insurance and its dimensions is given, touching also on the most important national markets. I shall then proceed to the various aspects of its overall economic role and the way it performs its functions.

In a quantitative sense, the importance of the world insurance industry is best described in terms of worldwide premiums written. Unfortunately, the eastern countries do not provide reliable statistical data, so we shall have to leave them out altogether.

According to estimates, the worldwide premium volume in 1981 was in the region of US-dollars 475 billion or some DM 1,070 billion. These figures represent the business written by primary or direct insurers. They do not include the business of reinsurers, who, as it is widely known, relieve the primary insurers of a portion of their risk, spreading it all over the world (Estimated worldwide premium volume in

* Chairman of the Board, Allianz Versicherungs-AG, Munich; address given before the Dortmund Chamber of Industry and Commerce on 10.2.1982. 
non-life reinsurance is about US-dollars 40 or 45 billion; there are no estimates available for life reinsurance.)

In the field of direct insurance, to which all the subsequent comments will refer, there are at present more than 10,000 companies operating throughout the world. Their number has more than quadrupled since the beginning of this century, and the trend is still upwards, especially in the third world countries.

Not surprisingly, the geographical distribution of worldwide premiums written shows that the highly developed industrial countries of the western world are also those having the most important insurance markets. The 24 OECD countries alone share about $95 \%$ of the global premium volume. There is thus a clear correlation between a country's overall standard of economic development and its insurance market. The United States hold, by a wide margin, the top rank among the national markets : this country alone accounts for approximately $45 \%$ of the world premium income. Then come Japan with a share in worldwide premium income of slightly less than $12 \%$, followed by the Federal Republic of Germany with just $11 \%$.

In Germany the premium income, which rose in 1981 by $9 \%$ to DM 86 billion, was written by over 800 insurance companies under federal supervision, with some 50 -odd companies representing about $75 \%$ of the business. Over 200,000 people are permanently employed in the insurance sector ; to these must be added the independent full-time and part-time agents as well as brokers. In total, the German insurance industry provides employment or additional occupation for about 450,000 people about as many as are employed in energy production and distribution, water supply and mining put together, and twice as many as in agriculture and forestry.

After this brief survey, which I hope has given a notion of the quantitative importance of the insurance industry, I shall now turn to its functional role within the economy as a whole. I would like to begin with a quotation which captures most vividly all the main features of this role. It is from Henry Ford, who as an automobile manufacturer must be regarded as a trustworthy and unbiased witness. Once he was showing the skyline of New York from the top of the Empire State building to a foreign visitor, who, deeply impressed, wondered how all this could have been built by human hands. "This city", Ford replied, "was not built by people but by insurers. Without insurers we would have no skyscrapers. Who would dare to work at such heights, if he ran the risk of a fatal fall leaving his family in need ? Without insurance no financier would invest his millions in buildings which can be reduced to ashes by a mere cigarette butt. No-one would even travel the streets without insurance."

I could proceed with this quotation for a while, but I will leave it at that. You can finish off the picture of the role played by insurance in modern society by adding that not a few of the skyscrapers before those two men's eyes were not merely covered by insurance companies, but had also been built by them, as an investment.

Economists approach these things in somewhat less picturesque but more precise terms of science. In analysing the overall economic function of insurance they differentiate between what may be called the commodity and the capital aspect of insurance.

From a commodity point of view, the analysis starts from the assumption that insurance protection is a commodity, a product, even though an invisible one, and accordingly refers to insurance as risk cover and a set of precautionary measures. 
As private individuals we are so well acquainted with the everyday concept of risk coverage that there is no need for me to discuss it at any length. In respect to business enterprises this is somewhat more complex, even if the underlying idea is basically the same. Every enterprise is exposed to specific risks, of which some especially the entrepreneurial risk - cannot be passed on to insurance companies, while others are insurable. Without insurance protection the businesses would often be unable to face the consequences of serious damage, and their very existence would be endangered.

Now this is where the economic function of insurance comes in. Fundamentally, it consists in reducing the proneness to disturbance - or in other words, in securing the proper functioning - of a complex economic system based on the principle of division of labour, further in reducing the sequels of damage and in strengthening the regenerative capacity of the economy, i.e. above all its capacity for further technical progress.

I would like to illustrate this by various practical examples. Technical progress has led in a number of industries to a significant increase in the size of the risks involved, and this is a development which continues apace.

In the 1950's, insurance transactions involving assets worth DM 10 million were regarded as peak risks. With ships and airplanes for instance, these proportions have undergone a drastic change. Some of the supertankers sailing the seven seas now represent an insured value of almost DM 400 million when fully loaded. And claims of this magnitude due to total loss through shipwreck are by no means rare events. But the insurers can also be hit in other ways, as in 1980, when three bulk carriers almost completed at an American shipyard had to be declared total losses as a result of construction defects. This cost the international insurance community over DM 600 million. Or take the Iraqi blockade of 73 merchant ships in the Persian Gulf. After a year's waiting and not sign of an end to the blockade, all these vessels were declared total losses. Lloyd's of London alone had to raise US-dollars 400 million.

As the property risks insured increased in size, so often do the attendant environmental hazards. You can no doubt remember the "black tide" of crude oil which, a few years ago, the foundered tanker Amoco Cadiz unleashed on the cost of Brittany. According to latest information, the French Government has lodged damage claims amounting to several billion of DM. Of this, however, "only" DM 133 million was insured by private companies within the framework of international liability agreements.

Sums similar to those involved in shipping are also found in aviation. The insured hull value of a Boeing 747 "Jumbo" can exceed DM 250 million. Accident and liability claims on behalf of passengers and third parties can easily add another DM 600-700 million. And this is unfortunately no mere theory. The collision of two Jumbo jets at Teneriffe in 1977 took a toll of 579 lives and cost the insurers USdollars 144.5 million. The recent disastrous accident suffered by a DC-10 at Boston through glazed frost on the runway will probably entail a claim of DM 100 million for the hull claim alone. Dependants of victims in the recent aircraft crash in Washington are suing the airline for damages amounting to DM 851 million as a test case, this is equivalent to DM 11.5 million for each of the 78 passengers killed. 
Technical progress involves not only a constant growth in scale and value of risks of the already existing kind, but also generates entirely new risks, satellite programms and space travel, for example. In this field too we are faced with vast concentrations of value, and here too the insurers have already experienced their first major claims. At the end of 1979 a communications satellite owned by the Radio Corporation of America disappeared without trace into space. Its total insured value amounted to over DM 170 million.

Among the typical products of novel technologies are the drilling rigs used to extract crude oil and gas from undersee deposits. Without insurance cover for these and similar risks (the so-called "offshore risks") this technique of obtaining raw materials now vital for the energy supply would be impracticable. A drilling rig in the North Sea costs up to DM 4 billion. Even the most sophisticated monitoring and safety devices cannot entirely eliminate the immense risks inherent in such installations. This was tragically demonstrated by the drilling rig Alexander L. Kielland in the Norwegian sector of the North Sea field. In March 1980 it sprang a leak and capsized with a loss of 123 lives. Over DM 150 million of the total loss will be assumed by the insurance companies.

The development of nuclear energy has broken new ground as regards both technology and underwriting. The accident at the Harrisburg nuclear power station in the U.S.A. led to total claims in the region of DM 1.2 billion, of which, however, only DM 650 million was covered by the international insurance industry. This is the most impressive instance of the risks and hazards encountered in this sector. Against the background of continental argument over the nuclear energy topic, the German insurance companies, which paid some DM 100 million of the Harrisburg claim, would of course be asked whether such risks are really insurable. In view of, especially, the extremely high safety standards of nuclear power plants in Germany, we answered "yes" even before Harrisburg. We still answer in the affirmative and provide the necessary insurance protection for investors, suppliers and operators of nuclear power plants.

With these few example I have tried to show that technological progress not only generates ever increasing risks (including some entirely new ones) but also that such a development would not have been possible without the insurance community assuming and limiting the concomitant risks.

The huge ventures of modern technology, whether in the aerospace, the marine or the atomic energy area, require equally enormous development funding and capital investment. But the economy will not make such investments unless the risks involved are largely insurable and thus made calculable. To this, the insurer has to contribute as does the engineer, the businessman and the financier.

But new types of major risks are not only brought about by technological developments. At the same time industrial enterprises find themselves confronted with more and more stringent liability regulations, whether enacted as laws or established by decisions of courts. I will not go into these complex legal issues in further detail, but I would like at least to mention the question of product or producer's liability, which constitutes a growing challenge to the international insurance community. This is especially true of the pharmaceutical industry. When the Contergan (thalidomide) 
drama showed the extent of risks inherent in pharmaceutical production, the German insurance industry reacted by forming so-called pharmaceutical insurance pools, through which the liability cover prescribed by law for the pharmaceutical industry is now provided. Maximum cover can be as high as DM 200 million per medicament.

The scope of liability regulations is likely to be extended, and there will be new liability factors arising in the future. The EEC commission is discussing a draft directive introducing the concept of strict product liability, i.e. liability irrespective of fault.

"Risk coverage" is one the spheres in which the insurance industry assumes functions essential for the whole of the economy. No less important are its functions in the sphere of social policy, especially as regards old-age and survivors' benefits. This applies to all western industrialised countries and particularly to the Federal Republic of Germany. As is well known, our social safety net in the old-age benefits area rests on three pillars. It consists first of basic protection for all wage-earners out of the social insurance system, secondly of pension schemes operated by companies on behalf of their employees, and thirdly of voluntary life insurance taken out by individuals.

Two of these three pillars, namely the company pension schemes and the individual life insurance policies, are partly or entirely within the scope of the life insurance industry. In 1981 private individuals and businesses in the Federal Republic of Germany spent about DM 32 million in life insurance premiums. Compared with the annual budget of the social old-age and survivors' insurance, which is more than twice as large, the business of the private insurance industry appears somewhat modest. However, it goes a long way towards easing the strain imposed on the social security system.

This relief function should not be endangered by further limiting the scope of private insurance, for instance by extending the collective State insurance system to cover the self-employed, merely with a view to fill the empty coffers. Just 100 years ago, Bismarck laid down the bases of German social policy, upon which the state social security system still rests. Since World war II, the scope of social security has been widened - at first slowly, then more rapidly, and finally at a headlong pace, until it has reached its financial limits. We have all witnessed the social zeal displayed by our politicians over the past few years, which weighed down our social security system with ever heavier burdens. This has led not only to financial problems for the carriers of State insurance, but to a spate of people's demands upon the State, the latter being perhaps even more serious because of its psychological and social implications. We in the insurance business view these trends with great anxiety. No less than $30 \%$ of our national income is currently devoted to "social " purposes, of which again a good half is earmarked by the social security system to cover the traditional risks of loss of income through old-age, sickness, accident and unemployment. This is a dangerously large proportion. Indeed, the funding problems of the social security budgets are serious hazards for the growth process of the economy as a whole. One can only agree with Otto Esser (President of the German Confederation of Employers' Associations) when he says that employers accept and appreciate the social security system, but believe that it should be brought back into line with the ability of the economy to support it. The private insurers are prepared to help develop this carrying capacity. They have already demonstrated that in comparison with the social security the cover they provide is at least as good if not better, and more worth its price. 
The private life insurance industry has also proved its efficiency in the field of company pensions schemes. Without the models worked out by private insurers, it would have been impossible to develop this important third pillar to the desirable extent.

It is particularly to the employees of small and medium-sized business, which cannot afford to set up pension funds of their own, that the life insurance companies are able to propose solutions suiting the security needs of these employees without putting an unreasonable strain on their employers. Some $60 \%$ of all wage-earners in the Federal Republic can now expect to obtain benefits from company pension schemes. To include the remaining employees is considered an important objective, all the more important as the Government has not exactly motivated the employers in this respect. For the actuarial rate of interest on pension provisions has been raised from 5.5 to $6 \%$ at the beginning of this year, and the businesses are required to wind up the reserves already accumulated.

The second large area of personal insurance is the private health insurance. Despite a comprehensive social health scheme, there is still a great need in the Federal Republic for private health cover. Out of a total of some 21 million people subject to compulsory social health insurance, more than 4 million regard additional private cover as necessary. Further 5 million citizens are insured with private insurers only, often holding several policies. Although the development of private health insurance in recent years has been strongly influenced by development in the sphere of social security, the industry has nevertheless succedded in steering a competitive course. While the statal system has been struggling for years with financial problems resulting from unsound policies aimed at expanding the benefits and involving further sections of the population, the private sector has avoided such pitfalls. It has gone the way marked out by external data, abiding by the reliable policy of applying tariffs commensurate to risks, it has carefully differentiated the services offered and replaced earlier tariffs stipulating for maximum benefit limits by tariffs granting $100 \%$ benefits but laying down fixed percentage retentions. Thus the private health insurers succeeds in keeping the rise in costs - and consequently tariff increases - at a lower average than the state insurance scheme. In 1981 they achieved a $10 \%$ growth in premium income to around DM 11 billion.

This concludes my remarks on the functions of covering risks and providing for the future.

I now turn to what economists call the capital-related role of the insurance business. Viewed from this angle, one can say, with some measure of simplification, that insurance put at the economies' disposal a fund supported by the national income, which on the one hand is used to cover claims and to finance productive activities on the other. The insurance business provides a constant supply of financial resources, which plays an important role in stabilizing the economic process and protects the structure of the market against random oscillations. In addition, this strengthens the investment capacity of the economy, thus making a significant contribution to the promotion of growth of the country and its further development. Both in its direct and indirect productive functions, the insurance sector is as indispensable for a developed economy as for instance banking and commerce. 
In connection with this function of insurance as a provider of financing, it should be emphasized that the investment the insurance industry makes in order to cover and to guarantee claims payments to clients must comply with stringent legal provisions. Security, profitability and liquidity are the prime criteria and the Federal supervisory office sees to it that these rules are observed.

These assets are of considerable size : in the Federal Republic, they amounted to over DM 300 billion at the end of 1981. The financial managers of all the insurance companies had almost DM 6 billion of new funds to invest in that year, amounting to about DM 240 million each working day.

The importance of the insurance sector for the German capital market is however only inadequately expressed in figures. This reason is not only the volume, but above all the quality of the funds assets made available both to business and to the public sector in the form of loans or equity capital.

The insurance business is far and away the most dependable and most abundant source of long-term funds. This has been confirmed by the Deutsche Bundesbank, which has emphasized above all the stability of the capital accumulation process in insurance. It has nevertheless detected a structural change in the insurers' investment policy, which is a response to the various challenges and stresses of recent years. This is especially the case with real estate and mortgages, which in the first half of the 1970's still represented a third of total investment volume. Since 1976 these types of investment steadily lost in importance, so that by the end of 1980 they only accounted for a quarter of total assets.

The situation in rental housing, a traditional investment of the insurance industry is a particular problematic one. Between 1950 and 1980, the insurance companies built in their investment portfolio some 187,000 dwelling units, at a total cost of barely DM 15 billion. In addition, significant amounts of capital for residential construction were provided by issueing mortgages and refinancing mortgage banks. During the same period, the German insurance industry thus supplied a total of over DM 130 billion for housing; by means of which some 3.3 million dwellings were built, or $21 \%$ of the dwellings in the whole of the Federal Republic. It is now publicly deplored that the extensive commitment has fallen off in recent years. It is unfortunately all too often overlooked that the insurance companies are tight down by law to strict profitability standards. In housing, these standards are increasingly difficult to meet. Accordingly, new investment in residential building was bound to decline. We greatly regret this, since with a view to mix our investment portfolio we would like to see our investments in real estate and related assets develop. But this implies appropriate legal and economic conditions.

The public sector share in new investments has on the other hand assumed an increasing role in insurers' investment portfolios since 1970. The aggregate fund provided by the insurance sector to public authorities both directly and through banks amount to about half of the new investments. This is a critically high proportion. There can be hardly any doubt that the Government is a highly reliable debtor for the time being, but if we extrapolate the development of public indebtness into the future, the question arises, for how long this can go on. A sober analysis must lead to the conclusion that the insurers are departing from their legal obligation to diversify and 
spread their investments. This is a disquieting conclusion, especially if one considers that such a development must be continued unless there is a fundamental change in governmental budgetary policies. This must lead to the insurers' inability to fulfil ideally their economic function of channeling the funds entrusted to them into investments affording at once a maximum security and productiveness.

I have already pointed out the market distortions that have emerged in real estate investment ; in this context one could also mention the situation of financial commitments in the industrial sector of the economy. Here too, the insurance industry is able and would like to supply more capital for the investment so urgently needed for the future. In the last resort, this again requires capital market functioning smoothly and not unduly drawn upon by the public sector.

Consolidation of the Gervenment budget is thus a vital prerequisite for the German insurers, if they are to fulfil their economically vital financial function to the best of their abilities.

I can drow the following conclusion :

Neither in the economy nor in the social community is sound development possible without the availability of insurance coverage.

Without the services provided by the private insurance industry we would not have been able in the Federal Republic to constitute the well-balanced social security system which is the envy of many countries.

Without the availability of insurance coverage, there would be, on account of the risks involved, none of the technical and technological developments which are indispensable for the economic progress.

Finally, without the capital collected and channeled back by the insurance companies, it would be hardly possible to supply the business community and the public sector with long term capital.

Private-sector insurance is thus itself supported by solid and reliable pillars. It is an integral part of the economy and is constantly called upon to master the growing risk problems. This is the case at many different levels, from the technical and business activities to personal insurance for private individuals. The further outlook for the insurer is thus closely bound up with the development of the overall economy, because of the inter-relationship I have described. This means that the slow-down in economic growth cannot remain without influence on the industry's latitude to grow.

This has already become evident over the past few years. Nevertheless, insurance will remain a relatively strong growth area in the years to come. It is to its advantage that the demand for insurance grows faster than the standard of living and the standard of economic and technological development of a country. 


\section{Dle volkswirtschaftllche Bedeutung der prlvaten Versicherungswirtschaft * - Fazlt/Zusammenfassung}

Weder in der Wirtschaft noch in der Gesellschaft wäre eine gesunde Entwicklung ohne Bereitstellung von Versicherungsschutz möglich.

Ohne das Leistungsangebot der privaten Versicherungswirtschaft hätten wir nicht das ausgewogene System sozialer Sicherung in der Bundesrepublik aufbauen können, um das uns viele Länder beneiden.

Ohne Bereitstellung von Versicherungsschutz wäre auch die technische und technologische Entwicklung, ohne die es keinen wirtschaftlichen Fortschritt gäbe, wegen der damit verbundenen Risiken für die Unternehmen undenkbar.

Schließlich wäre ohne das von der Assekuranz "gesammelte" und von ihr zurückkanalisierte Kapital die Versorgung der Wirtschaft und der öffentlichen Hände mit langfristigen Finanzierungsmitteln kaum möglich.

Die Individualversicherung selbst steht daher auf sicheren, soliden Pfeilern. Sie ist fest in die Volkswirtschaft eingebettet und wird immer stärker zur Bewältigung schwieriger Risikoprobleme herangezogen. Dies ist der Fall auf unterschiedlichen Ebenen, sei es auf dem Sektor technischer und unternehmerischer Tätigkeiten, sei es auf dem Sektor individueller Personenversicherung.

Das weitere Schicksal der Assekuranz ist aufgrund der beschriebenen Zusammenhänge eng mit der Entwicklung der Gesamtwirtschaft verknüpft. Das bedeutet, daß das Nachlassen des gesamtwirtschaftlichen Wachstums nicht ohne Einfluß auf ihren eigenen Wachstumsspielraum bleiben wird.

Dies hat sich in den letzten Jahren bereits gezeigt. Trotzdem wird die Assekuranz auch in den vor uns liegenden Jahren eine relative Wachstumsbranche bleiben. Ihr kommt zugute, daß die Nachfrage nach Versicherungsschutz mit zunehmendem Lebensstandard und zunehmendem wirtschaftlich-technischem Einwicklungsstand eines Landes überproportional wächst.

* Vortrag von Dr. Wolfgang Schieren, Vorsitzender des Vorstands, Allianz Versicherungs-AG, München, gehalten vor der Industrie- und Handelskammer Dortmund am 10.2.1982. 